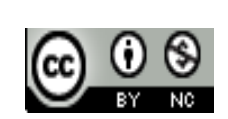

Jurnal Pendidikan Bahasa dan Sastra Indonesia is licensed under

A Creative Commons Attribution-Non Commercial 4.0 International License

\title{
Alih Fungsi Hutan Sumatera dalam Novel Luka Perempuan Asap Karya Nafi'ah Al-Ma'rab
}

\author{
Frans Apriliadi ${ }^{1)}$, Anwar Efendi ${ }^{2)}$ \\ 1) Mahasiswa Program Pendidikan Bahasa dan Sastra Indonesia, Pascasarjana, Universitas Negeri Yogyakarta \\ E-mail: fransapriliadi@gmail.com \\ ${ }^{2)}$ Dosen Program Pendidikan Bahasa dan Sastra Indonesia, Pascasarjana, Universitas Negeri Yogyakarta \\ E-mail: efendianwar@ymail.com
}

\begin{abstract}
Abstrak. Penelitian ini bertujuan untuk menjelaskan dampak alih fungsi hutan dan upaya menjaga lingkungan dalam novel Luka Perempuan Asap karya Nafi'ah Al-Ma'rab dengan perspektif ekokritik. Metode penelitian yang digunakan adalah deskriptif kualitatif. Data yang diperoleh diuji secara validitas semantik dan reliabilitas melalui kegiatan membaca secara berulang-ulang. Data selanjutnya dianalisis dengan empat tahap, yaitu pengumpulan, reduksi data, penyajian, dan kesimpulan. Hasil penelitian memberikan gambaran sebagai berikut. Pertama, dampak yang ditimbulkan dari alih fungsi hutan menjadi perkebunan sawit, seperti berkurangnya kandungan air tanah, tanaman di sekitar sawit mati, pemanasan global, kebakaran hutan, kabut asap, gangguan pernapasan dan kematian. Kedua, upaya mencegah kerusakan lingkungan dari alih fungsi hutan menjadi perkebunan sawit adalah dengan mengubah pola pikir masyarakat kembali kesistem pertanian agraris, memperketat perizinan, melaksanakan uji kelayakan dan analisis lingkungan oleh lembaga kredibel. Berdasarkan penjelasan tersebut novel Luka Perempuan Asap mengajakarkan kepada pembaca agar tidak melakukan bentuk-bentuk pengintimidasian terhadap alam secara berlebihan. Pengintimidasian terhadap alam secara tidak langsung menimbulkan banyak masalah yang berdampak buruk bagi lingkungan dan makhluk hidup di sekitarnya.
\end{abstract}

Kata Kunci: alih fungsi; hutan; lingkungan; ekokritik

\section{PENDAHULUAN}

Alih fungsi yang terjadi di Indonesia menunjukan ambang kekhawatiran. Peralihan fungsi hutan menjadi lahan perkebunan sawit berdampak buruk bagi kerusakan hutan, degradasi dan eksploitasi lingkungan sehingga menjadi persoalan serius yang harus ditangani semua pihak. Provinsi Riau merupakan salah satu provinsi yang terimbas kebiakan ini. Semenjak tahun 2013-2016 luas hutan Indonesia mengalami kemerosotan sebanyak 718 hektar (Barri, dkk., 2016:2). Alih fungsi dengan cara illegal loging dan pembakaran lahan telah mengubah 2 juta hektar tata guna lahan di Riau, padahal 3,9 juta hektarnya merupakan kawasan gambut yang terus mengalami degradasi sehingga menimbulkan polusi udara, emisi gas rumah kaca, dan pemanasan global (Darjono, 2003:73; Darmawan, dkk., 2016: 196). Kondisi ini menunjukan kondisi hutan Indonesia dan kerusakannya menjadi sorotan dunia.

Perkebunan sawit di Indonesia terus mengalami peningkatan. Terhitung sejak 1960-an rentang penambahan area sawit mencapai 200.000 hektar setiap tahun dan dianggap meningkatkan perekonomian negara. Namun, perkebunan sawit juga menimbulkan kerugian yang berindikasi pada kerusakan dan pencemaran lingkungan. Negara maju dan organisasi peduli lingkungan menuding perkebunan sawit menjadi penyebab utama hilangnya kawasan hutan Indonesia (Masykur, 2013:96-99). Kondisi inilah yang ingin digambarkan Nafi'ah Al-Ma'rab dalam novel Luka Perempuan Asap sebagai realita yang teradi di Riau dengan maksud terbangun rasa peduli dan prilaku menjaga lingkungan yang terefleksi dalam kehidupan nyata.

Berdasarkan hal itu, pembahasan ini akan dikaji dengan perspektif ekokritik. Ekokritik menjadi gerakan dalam melawan segala bentuk eksploitasi lingkungan yang sematamata menindas bumi (Pranoto, 2014:3). Gerarrd (2004:4) mengatakan kehadiran ekokritik sebagai sarana manusia untuk menyelesaikan beragam problematika ekologi. Teori ekologi membantu kajian sastra dalam mengungkapkan gagasan tentang lingkungan, termasuk juga nilai-nilai kearifan. Secara tidak langsung, ekokritik memberikan kebebasan dalam melakukan analisis mengingat sastra lahir, berkembang, dan berdasar dari lingkungan masyarakat dan alam (Hardiningtyas, 2015:128). 
Kehadiran ekokritik dalam kajian sastra menjadi perhatian bahwa sebenarnya lingkungan perlu diperhatikan keberadaan dan eksistensinya. Lingkungan menjadi bagian ekosistem dan kelangsungan hidup manusia bukan sebagai tempat penjarahan dan eksploitasi untuk kepetingan pribadi.

Berangkat dari pandangan tersebut, pembahasan ini mencoba mengkaji novel Luka Perempuan Asap dengan perspektif ekokritik untuk mendeskripsikan dampak alih fungsi kawasan hutan dan upaya menjaga kawasan hutan dari alih fungsi dalam novel Luka Perempuan Asap.

\section{METODE}

Sumber data penelitian ini adalah novel Luka Perempuan Asap karya Nafi'ah Al-Ma'rab (Sugiarti). Data diperoleh melalui teknik pembacaan dan pencatatan untuk menemukan hal-hal yang berhubungan dengan rumusan masalah. Penelitian menggunakan tabulasi data untuk mencatat temuantemuan pada saat membaca novel dan peneliti menjadi orang yang paling memahami penelitian (human instrument). Data yang diperoleh selanjutnya dikaji dengan teknik deskriptif kualitatif berdasarkan teori ekokritik. Uji data dalam pembahasan ini dilakukan secara uji validitas semantik dan uji reliabilitas dengan membaca dan pengecekan secara berulangulang. Hasil akhir penelitian dilakukan berdasarkan empat tahap analisis data, yaitu pengumpulan, reduksi, penyajian, dan pembuatan kesimpulan (Mills \& Huberman, 1984:23).

\section{HASIL DAN PEMBAHASAN}

Adapun hasil temuan pada penelitian ini adalah sebagai berikut.

Tabel 1. Hasil Temuan Penelitian

\begin{tabular}{|c|c|c|}
\hline \multicolumn{3}{|c|}{ Alih Fungsi Hutan Sumatera } \\
\hline 光 & $\begin{array}{c}\text { Dampak Kerusakan } \\
\text { Lingkungan }\end{array}$ & Upaya Menjaga Lingkungan \\
\hline Uే & $\begin{array}{l}\text { - } \text { Berkurangnya } \\
\text { kandungan tanah } \\
\text { - Tanaman di sekitar } \\
\text { sawit mati } \\
\text { - Pemanasan global } \\
\text { - Kebakaran hutan } \\
\text { - Kabut asap } \\
\text { - Gangguan } \\
\text { - Kernapasan } \\
\text { - Kematian }\end{array}$ & $\begin{array}{l}\text { - Menolak kebijakan alih } \\
\text { fungsi hutan } \\
\text { - Kembali ke sistem pertanian } \\
\text { agraris } \\
\text { - Memperketat perizinan } \\
\text { - Uji kelayakan dan analisis } \\
\text { lingkungan }\end{array}$ \\
\hline
\end{tabular}

Novel Luka Perempuan Asap menunjukan bahwa alih fungsi kawasan hutan menjadi perkebunan sawit di daerah transmigrasi Provinsi Riau menimbulkan kerusakan lingkungan, sehingga memerlukan upaya untuk menjaga lingkungan dari bentuk-bentuk pengerusakan. Adapun hasil temuan ditunjukan dalam Tabel 1. Berikut penjelasan dari hasil temuan tersebut.

\section{Dampak Alih fungsi Hutan menjadi Perkebunan Sawit dalam Novel Luka Perempuan Asap}

Alih fungsi hutan menjadi perkebunan sawit dalam novel Luka Perempuan Asap digambarkan sebagai bentuk penjarahan hutan yang dilakukan dengan cara yang salah. Bentuk penjarahan ini semata-mata digambarkan dalam upaya untuk memperoleh keuntungan sebanyak-banyaknya. Bentuk penjarahan bermula karena keserakahan tokoh Kang Marsono dan anaknya Marjo yang menipu Ayah Mun (Pak Gan) yang merupakan sahabatnya sendiri untuk investasi membuka kebun sawit yang tidak memerlukan pengawasan, karena telah disediakan penjaga yang siap patroli siang dan malam. Harga sawit yang tergolong tinggi juga menjadi penyebab Pak Gan tertarik berinvestasi 500 juta untuk 1000 hektar perkebunan sawit.

Uang 500 juta yang awalnya digunakan Kang Marsono untuk membuka lahan kebun sawit baru terancam gagal karena ada kelompok mengatasnamakan organisasi peduli lingkungan menolak dengan keras penanaman sawit. Salah satu anggota kelompok tersebut adalah Mun (anak Pak Gun) yang melakukan penelitian tentang sawit bersama Ibu Wilda (pembimbing Mun) seorang dosen yang berkejasama dengan LSM Asing untuk menghentikan perusakan lingkungan. Awalnya Mun menolak karena orang tuanya adalah juragan sawit dan banyak orang di kampungnya hidup dari sawit. Namun, karena desakan dan ancaman tidak diluluskan, akhirnya Mun melaksanakan arahan $\mathrm{Bu}$ Wilda. Bu Wilda menganggap sawit menimbulkan dampak yang mengerikan bagi kelangsungan tanaman dan kandungan air di sekitarnya. Perhatikan kutipan berikut.

(1) "Kamu tahu tanaman sawit itu sangat membahayakan lingkungan, termasuk tanah yang ada di sekitarnya. Konon dalam sehari, sebatang sawit bisa menghabiskan banyak sekali air untuk kehidupan akarnya" (LPA, 2017: 58).

(2) "sawit telah menghabiskan banyak air, dalam sehari lebih dari dua belas liter air dipakai oleh satu batang sawit untuk memproduksi buahnya. Bisa Bapak bayangkan kekeringan akan terjadi? Bapak akan lihat semua tanaman di sekitar sawit itu mati, bakan bisa menjadi halaman rumah Bapak sendiri. Semua tanaman kering karena air yang habis diserap" (LPA, 2017: 177).

Kutipan 1 dan 2 menjelaskan bahwa sawit merupakan tanaman rakus air sehingga dikhawatirkan akan mengganggu persediaan air di wilayah yang merupakan resapan air, belum lagi limbah sawit yang tidak dikelola dengan baik dapat mencemari lingkungan (Adhynugraha, 2006:68). Walaupun kondisi ini masih menjadi perdebatan karena secara tidak langsung, sawit juga dianggap meningkatkan perekonomian Negara. Pada satu sisi, perkembangan sawit menyebabkan ketersediaan air di sekitarnya menurun sehingga dapat menyebabkan ketersediaan air di suatu wilayah berkurang. Berdasarkan kondisi tersebut, penanaman sawit perlu 
dilakukan uji analisis terlebih dahulu oleh lembaga kredibel dibidangnya.

Lembaga penggiat peduli lingkungan hidup mengingatkan bahwa sawit dapat mengubah lahan hijau yang subur, ditumbuhi beragam tanaman menjadi dataran kering. Perubahan fisik tanah pun terjadi, seperti penurunan kandungan tanah pada kedalaman tanah liat, penurunan bahan organik, penurunan indeks stabilitas agregat tanah pada kedalaman 0-20 dan 20-40 cm sejalan dengan usia hidup sawit sampai sawit tidak bisa digunakan lagi (Simarmata, Rauf, \& Hidayat, 2017:191). Sawit menyebabkan kawasan menjadi gersang, tumbuhan dan tanaman mengering sehingga rawan terjadi kebakaran hutan. Selain itu, penanaman sawit mengharuskan alih fungsi kawasan hutan sehingga fungsi hutan sebagai pensuplai oksigen berkurang, akhirnya berdampak pada pemanasan global. Hal ini menunjukan penanaman sawit dalam jangka panjang menimbulkan dampak yang mengerikan seperti yang ditunjukan dalam kutipan 3 dan 4 berikut.

(3) "Lihatlah sekarang, Mun, sudah hampir tiga bulan hujan tak turun di Riau. Kamu tahu apa sebabnya? Cuaca sangat gersang. Titik api mulai muncul di mana-mana" (LPA, 2017: 133).

(4) "Bumi di tanah itu kian memanas. Hijau daun yang menjulur di setiap dahan seolah tiada meneduh di bawahnya. Orang-orang tidak peduli lagi pada hijau batang-batang sawit. Sebab, panas telah kian merajalela. Di bagian ujung-ujung daun warnanya telah berubah, kuning coklat dan akhirnya rontok ke tanah. Angin yang bertiup hanya sesekali. Sementara panas yang menyeruak terasa hingga ke bilik kamar. Rumah-rumah tiada henti memutar kipas angin" (LPA, 2017:137).

Kondisi bumi yang semakin panas dan tanaman yang mengering menjadi keuntungan tersendiri bagi sekelompok orang untuk mencari keuntungan. Untuk membuka lahan baru, masyarakat lebih memilih dengan cara membakar hutan. Langkah ini dipilih mengingat dengan cara seperti ini tidak memerlukan biaya yang banyak. Cuaca yang panas dan dedaunan yang mengering menjadi alasan lain menggunakan cara tersebut. Perhatikan kutipan berikut.

(5) "Kemarin lahan sawitnya sudah mulai dibuka. Tapi karena cuaca lagi panas, jadi lebih baik kita pilih pembakaran saja" (LPA, 2017:144).

Kutipan 5 mengindikasikan bahwa pembakaran hutan merupakan suatu perbuatan yang dilakukan secara sengaja. Pembukaan lahan baru dengan cara membakar hutan menimbulkan banyak kerugian, seperti berdampak pada kesehatan dan hilangnya mata pencarian masyarakat karena asap pekat yang mengganggu pernapasan dan jarak pandang. Kondisi ini jika dibiarkan berlanjut menyebabkan banyak orang terkena penyakit infeksi saluran pernafasan atas (ISPA) dan gangguan kesehatan lainnya. Perhatikan kutipan berikut.
(6) "Di suatu pagi, langit terlihat memutih. Matahari hanya tampak sedikit. Cuaca menjadi redup, sedikit demi sedikit hingga siang hari matahari tak tampak lagi. Langit sempurna memutih seutuhnya. Tetapi, matahari yang hilang justru membuat persoalan. Sebab, yang datang justru jerubu yang berkepanjangan. Orang menunggu di setiap pagi kalau-kalau matahari akan muncul. Tetapi, itu hanyalah penantian. Langit semakin memutih, bahkan kekuningan. Putih itu kian turun ke bumi, ke udara, hingga jalan-jalan semuanya menjadi putih. Nahas, putih itu rupanya membawa malapetaka. Siapa yang menghirupnya akan celaka. Ada yang singgah di rumah sakit, ada yang mengunci diri di kamar setiap saat, da nada pula yang dibawa ke unit gawat darurat" (LPA, 2017: 153-154).

(7) “Asap, tentu saja asap penyebabnya. Kalian tahu, dokter bilang ada gumpalan seperti awan di dada anak saya, itu asap. Asap sudah membunuh anak saya. Kalau kalian bisa apa? .... iya, memangnya kenapa? Asap ini sudah seluruh Indonesia, hitung saja beberapa jumlah korbannya di Indonesia" (LPA, 2017:158).

Kutipan 6 dan 7 menunjukan jumlah korban akibat kabut asap cukup mengkhawatirkan. Bencana kabut asap yang terjadi pada 2015 menunjukan 6,3 juta jiwa di 12 Kabupaten/Kota penduduk Riau yang terpapar asap dan 31.518 jiwa menderita gangguan pernapasan. Data tanggal 29 Juni-29 Oktober 2015 teridentifikasi sebanyak 83,9 \% menderita ISPA, 6,07\% jiwa mengalami iritasi dan penyakit kulit, 4,83\% mengalami iritasi mata, 3,83\% mengalami penyakit asma, dan $1,34 \%$ mengalami pneumonia. Kondisi ini menunjukan polusi udara mencapai pada indikator sangat berbahaya, yaitu mencapai nilai 799 dan tertinggi dibandingkan provinsi-provinsi lain (Dinas Kesehatan Provinsi Riau dalam Awaludin, 2016:39).

Kondisi udara yang tidak layak tidak hanya berbahaya bagi kesehatan karena menyebabkan gangguan pernafasan, akan tetapi juga berbahaya bagi kondisi janin dalam kandungan, anak-anak, dan orang tua. Data tersebut belum menunjukan korban yang meninggal dunia karena bencana kabut asap, termasuk juga jumlah korban disejumlah provinsi lain dan negara tetangga. Pada hal ini, negara juga menanggung kerugian yang besar sehingga kabut asap dikategorikan sebagai bencana nasional.

\section{Upaya untuk Mencegah Terjadinya Kerusakan Lingkungan dalam Novel Luka Perempuan Asap}

Alih fungsi hutan menjadi perkebunan sawit menimbulkan perlawanan dan kekhawatiran sebagian orang. Perlawanan terhadap aktivitas masyarakat mengubah alih fungsi hutan menjadi perkebunan sawit dalam novel Luka Perempuan Asap direpresentasikan oleh tokoh $\mathrm{Bu}$ Wilda (dosen sekaligus anggota LSM) dan masyarakat desa.

$\mathrm{Bu}$ Wilda sendiri merupakan seorang dosen tempat Mun berkuliah dan pembimbing skripsi Mun. Di balik profesinya sebagai seorang dosen, ternyata $\mathrm{Bu}$ Wilda juga bekerja 
sebagai anggota lembaga pencinta lingkungan yang disponsori lembaga asing. Lembaga tersebut berlokasi di Amerika yang bergerak melakukan perlawanan terhadap segala bentuk pengintimidasian lingkungan, salah satunya di Riau. Melalui profesinya sebagai dosen, $\mathrm{Bu}$ Wilda melakukan penelitian untuk membatalkan peralihan fungsi hutan menjadi perkebunan sawit dengan bantuan penelitian mahasiswa bimbingannya. Akan tetapi, penelitian yang dilakukan mahasiswanya tersebut hanya sebagai kedok menutupi riset organisasinya tersebut.

Mun sebagai salah satu mahasiswa bimbingannya dipaksa untuk melakukan riset tentang dampak perkebunan sawit bagi lingkungan. Selanjutnya, data penelitian yang dilakukan Mun dijadikan dasar untuk memerangi perlusaan kebun sawit di Riau. Bentuk perlawanan yang dilakukan $\mathrm{Bu}$ Wilda dalam memerangi perluasan perkebunan sawit direalisasikan dalam ucapan, sikap, dan tindakannya dalam mencari data agar perusahaan yang ingin membuka lahan baru gagal secara hukum. Perhatikan kutipan berikut.

(8) "Begini samua, sekarang ada proyek analisis dampak lingkungan. Kamu tahu tanaman sawit itu sangat membahayakan lingkungan, termasuk tanah yang ada di sekitarnya. Konon dalam sehari, sebatang sawit bisa menghabiskan banyak sekali air untuk kehidupan akarnya. Tugas kamu menghitung berapa banyak air yang diserap oleh sawit itu per batang per hari. Dengan data ini maka semakin kuat upaya kita untuk memerangi sawit di provinsi Riau” (LPA, 2017:58).

Kutipan 8 menunjukan bentuk kecintaan dan kepedulian $\mathrm{Bu}$ Wilda terhadap hutan di Riau melalui prilaku dan sikapnya, ketika melihat kobaran api yang membakar lahan oleh kelompok orang yang tidak bertanggung jawab. Menurut sudut pandangnya, perbuatan membakar hutan merupakan prilaku yang salah. Berbeda dengan cara berpikir Mun yang berpikiran membakar lahan untuk membuka lahan baru merupakan hal yang biasa dan sering dilakukan oleh penduduk di kampungnya. Walaupun sebenarnya kepedulian $\mathrm{Bu}$ Wilda pada lingkungan tidak sepenuhnya murni, tetapi hanya berdasarkan materi. Perhatikan kutipan berikut.

(9) “Apa yang kusaksikan sebenarnya bukan sesuatu yang asing. Pun di kampung banyak orang membakar lahan. Tetapi, kali ini aku punya status yang berbeda sebagai peneliti. Ku lihat Bu Wilda sibuk menelepon ke sana sini. Meski dalam kondisi asap yang kian mendekat, wajah Bu Wilda justru tampak kian girang. ... seharusnya, jika dia memang seorang peneliti, mestinya dia prihatin dengan apa yang terjadi...."

"mun, kita akan berhasil."

"Berhasil apanya, Bu?"

"Mencegah proyek ini. Kamu masih sismpan fotofoto tadi, kan? Ini akan jadi delik dan kita akan menang." (LPA, 2017:104-105).

Kepedulian lingkungan yang dilakukan $\mathrm{Bu}$ Wilda pada dasarnya mendapatkan kritik dari Mun yang tidak suka proyek tersebut bekerjasama dengan pihak asing. Pada sisi lain, Mun juga menolak dikarenakan Mun hidup dan dapat kuliah dari hasil sawit ayahnya, warga di kampungnya juga sebagian besar hidup dari bertani sawit. Akan tetapi $\mathrm{Bu}$ Wilda tetap bersikeras walaupun berkerja sama dengan pihak asing, dikarenkan apa yang dilakukannya merupakan perbuatan yang benar. Perhatikan kutipan berikut.

(10) "tapi, itu semua dilakukan dengan lembaga asing kan, Bu?"

"Apa salahnya? Toh yang dilakukan benar. Sawit memang mencemari lingkungan dan pertumbuhannya harus dicegah. Lingkungan kita harus sehat."

"Tapi, orang-orang di kampung saya bisa hidup karena sawit, Bu. Ada ribuan orang di sana. Mereka menjadi sejahtera karena sawit. Saya pun bisa kuliah karena sawit. Kami sangat tergantung pada sawit”

"Jangan berpikir egois, mereka bisa saja bahagia sekarang, tapi bagaimana dampaknya yang akan datang? Lingkungan akan hancur (LPA, 2017:131132).

(11) "kenapa kita memikirkan nasib satu orang, lalu mengabaikan nasib ribuan orang? Lihatlah sekarang, Mun, sudah hampir tiga bulan hujan tak turun di Riau. Kamu tahu apa sebabnya? Cuaca sangat gersang. Titik api mulai muncul di mana-mana." (LPA, 2017:133).

Perlawanan terhadap aktivitas alih fungsi kawasan hutan juga dilakukan oleh penduduk tempat tinggal Mun. Perlawanan warga desa terhadap lingkungannya dapat dikatakan terlambat. Betapa tidak, setelah kebakaran hutan yang menyebabkan kabut asap menyelimuti seluruh provinsi dan menimbulkan korban jiwa barulah masyarakat tergugah perasaannya, menyadari perbuatan yang mereka lakukan selama ini adalah salah. Belum lagi kekecewaan mereka bertambah besar dikarenakan mereka merasa ditipu dan dibodohi oleh perusahaan yang ingin membuka lahan. Warga desa bekerja di bawah paksaan dan bayang-bayang ditangkap pihak keamanan.

Bentuk sikap tidak terima yang ditunjukan warga desa akibat keserakahan orang luar di kampung mereka ditunjukan dalam kutipan berikut.

"kalian kenal pengusaha itu?"

"tentu saja, Bu, dia bukan orang sini. Dia orang luar yang coba mencari keuntungan dari kampung kami."

"lalu, bagaimana Pak?"

"Kami akan laporkan dia, Bu. Kami akan bersaksi untuk kejahatan yang sudah dia lakukan." (LPA, 2017: 174).

(13) “....ini tanah kampung kami, tapi mereka menguasai. Kami tak mau lagi orang mengeruk keuntungan dari tanah kami. Ini tanah datuk-datuk kami, tak patut rasanya orang-orang dating ke sini hendak mencari keuntungan.."( LPA, 2017:175). 
(14) "kawan-kawan, kita orang Malayu haruslah menjadi tuan di tanah sendiri. Tanah ini tanah kita, kitalah yang harus mempunyainya, jangan suruh orang luar datang kemari lalu menikmatinya, habislah kita. Jangan lagi ada orang yang bertanam surga di tanah kita, sedang kita tetap sengsara begini. Kita harus kawal siapa saja yang ingin mencari keuntungan di tanah kita. Tanah kita haruslah kita jaga.

"jadi, jangan ada lagi pembukaan kebun sawit di tanah kita oleh orang-orang luar, setuju...?” (LPA, 2017: 178).

Kutipan 12-14 menjelaskan bahwa petani Indonesia mempunyai hak yang lebih besar dalam mengelola lahan sebagai tempat bercocok tanam. Berdasarkan data perusahaan asing yang menguasai perkebunan sawit di Indonesia berasal dari Malaysia (4 perusahaan), Inggris (3 perusahan), Belgia (1 perusahaan), Luxemburg (1 perusahaan), Singapura (1 perusahaan), Amerika Serikat (1 perusahaan), dan Srilangka (1 perusahaan). Kepemilikan perkebunan sawit di Riau paling banyak dikuasai oleh Malaysia mencapai 500.000 hektar (Tayibnapis, 2013: 51).

Kondisi ini menjadi kritik tersendiri bagi pemerintah, jangan sampai pengusaha asing meraup untung dari kepemilikan sawit di Riau, sementara masyarakat Indonesia hanya dijadikan sebagai buruh kasar mereka. Hasil dari perkebunan tersebut sepenuhnya harus menjadi milik petani, bukan semata menjadi milik orang lain atau perusahaanperusahaan asing. Terlebih lagi, petani yang sebagian besar merupakan masyarakat di sekitar wilayah tersebut tidak menjadi buruh kasar bagi perusahaan asing tersebut.

Upaya yang dilakukan tokoh dalam menjaga lingkungan adalah dengan mengubah pola pikir masyarakat untuk kembali kepada sistem pertanian yang tidak merusak lingkungan, tidak merusak tanah dan tidak membuka lahan dengan cara membakar hutan. Ajakan untuk kembali kesistem pertanian agraris yang ramah lingkungan menjadi pilihan. Perhatikan kutipan berikut.

(15) "Dengan kegigihan dan perjuangannya, Ayah membuka lahan yang bak hutan menjadi perkebunan sayur-mayur. Ayah dan Ibu berhemat sampai akhirnya mereka mengembangkan kebun dari empat hektar yang diberi pemerintah hingga kini menjadi ratusan hektar" (LPA, 2017: 33).

(16) "Bapak-bapak di sini menjadi benteng penyelamatan bumi. Kembalilah ke tanaman-tanaman palawija yang tidak membunuh tanah. Itu lebih baik dan aman." LPA, 2017: 177).

Kutipan 15 dan 16 menjelaskan bahwa sebenarnya isu kerusakan lingkungan yang selama ini terjadi akibat penanaman sawit, pembebasan lahan, dan hal-hal yang menyertainya menjadi perhatian khusus. Kondisi ini memerlukan strategi pengelolaan lingkungan pertanian yang terencana dengan baik, terarah, dan sesuai dengan kaidah- kaidah pengolahan yang sudah ada. Tanaman yang ditanam merupakan tanaman agraris seperti biji-bijian, sayur-sayuran, buah-buahan, dan jenis-jenis tanaman organik lainnya. Pertanian agraris pada dasarnya juga tidak terlepas dari permasalahan kerusakan lingkungan, seperti penggunaan peptisida, zat kimia untuk mempercepat pertumbuhan tanaman dan lain sebagainya. Akan tetapi, kerusakan lingkungan dari pertanian agraris tidak sebesar kerusakan lingkungan akibat penanaman sawit yang dampaknya jangka panjang.

Pengolahan lingkungan juga memerlukan pengujian riset agar hal-hal yang berdampak pada kerusakan lingkungan dapat diatasi dan ditanggulangi secepatnya, sebelum pemberian izin untuk membuka lahan perkebunan. Pengkajian dan analisis lingkungan merupakan salah satu upaya mencegah kerusakan lingkungan kedepannya. Perhatikan kutipan berikut.

(17) “...kami belum bisa memberikan izin pembukaan lahan tersebut. Setidaknya, ada lembaga lingkungan yang akan menganalisisnya terlebih dahulu. Kalau hasilnya tidak membahayakan, kami izinkan pembukaan lahannya, tetapi kalau hasil riset justru sebaliknya, kami mohon maaf. Kami tidak bisa mengeluarkan izin lahan tersebut.” (LPA, 2017:95).

Kutipan 17 menunjukan bahwa kontrol pemerintah dan lembaga yang bergerak pada bidang lingkungan terhadap kebijakan dan implementasi kebijakan menjadi sangat penting. Aturan yang benar selain memberikan batasan kepada pihak yang semena-mena membuka lahan tanpa memperhatikan dampak lingkungan, juga untuk mengontrol pihak-pihak yang cenderung berpihak pada perusahaan yang dianggap mempunyai kontribusi dalam meningkatkan pendapatan daerah dan nasional. Semua pihak yang menggunakan kawasan hutan harus seizin Menteri Kehutanan. Sesuai dalam UU Nomor 5 Tahun 1990 yang mengatakan terkhusus kawasan konservasi, taman nasional, dan cagar budaya diawasi oleh Dirjen PHKA (BKSDA dan Balai Taman Nasional). Sementara hutan lindung dan produksi diawasi Gubernur dan Bupati. Pelaksananya diatur dalam tata guna hutan sesuai kesepakatan (TGHK) (Abadi \& Rusli, 2014: 308).

Pembukaan lahan baru juga memerlukan izin dari lembaga yang kredibel dalam menguji kelayakan daerah yang akan ditanam pohon sawit. Umumnya terdapat beberapa hal yang perlu diperhatikan selain mendapatkan izin dari pemerintah tentang undang-undang dan peraturan pertanahan, yaitu kelangsungan keanekaragaman hayati dan satwa liar, pengaturan pembuangan limbah dan tanggung jawab ekonomi, sosial dari perusahaan pengelola perkebunan (Masykur, 2013: 102).

Berdasarkan penjelasan tersebut terdapat nilai penting yang ingin disampaikan oleh penulis dalam novel Luka Perempuan Asap bahwa lingkungan menjadi suatu yang penting bagi kelangsungan manusia. Kawasan hutan dan segala problematikanya menjadi tempat manusia merenung, berefkeksi, dan bercermin terhadap segala perbuatan yang selama ini dilakukan pada alam. Nafi'ah Al-Ma'rab 
membangun relasi dalam benak pembaca tentang pentingnya menjaga kawasan hutan dalam relasi kepercayaan antara manusia. Hutan dengan segala kekayaannya haruslah dimanfaatkan sebagaimana mestinya, dimanfaatkan untuk kepetingan masyarakat di sekitarnya bukan semata-mata untuk kepentingan salah satu pihak atau negara lain.

\section{IV.SIMPULAN DAN SARAN}

\section{SIMPULAN}

Berdasarkan pembahasan dapat diambil kesimpulan sebagai berikut. Pertama, dampak dari kebijakan alih fungsi kawasan hutan menjadi perkebunan sawit dalam novel Luka Perempuan Asap menyebabkan terjadinya beberapa bencana. Bahkan bencana yang ditimbulkan sampai pada tingkat nasional. Adapun dampak yang ditimbulkan, seperti penanaman sawit berdampak yang buruk bagi kelangsungan tanaman dan kandungan air di sekitarnya karena sifatnya yang rakus air menyebabkan kawasan di sekitar pohon sawit menjadi dataran kering, menyebabkan pemanasan global, kebakaran hutan yang menimbulkan kabut asap berkepanjangan, dan beragam penyakit karena gangguan pernafasan.

Kedua,upaya untuk mencegah terjadinya kerusakan lingkungan adalah dengan menolak alih fungsi hutan menjadi perkebunan sawit, mengubah pola pikir masyarakat untuk kembali kesistem pertanian agraris dan meninggalkan perkebunan sawit. Perizinan bagi perusahaan asing yang ingin memperluas lahan sawitnya perlu diperketat, uji kelayakan, dan analisis lingkungan oleh lembaga kredibel.

Berdasarkan pembahasan tersebut, novel Luka Perempuan Asap menggambarkan akan pentingnya menjaga lingkungan. Hutan harus dimanfaatkan seperlunya. Novel Luka Prempuan Asap mengajarkan kepada pembaca agar tidak melakukan bentuk-bentuk pengintimidasian terhadap alam secara berlebihan. Pengintimidasian terhadap alam di luar ketentuan yang diperlukan akan menimbulkan banyak masalah. Masalah yang muncul akan berdampak buruk bagi lingkungan dan makhluk hidup di sekitarnya.

\section{SARAN}

Penelitian ini dapat dikatakan sebagai penelitian yang belum sempurna. Maka, diperlukan masukan dan saran dari segala pihak untuk memperbaiki, sehingga hasil penelitian yang diperoleh memberikan gambaran yang diharapkan.

\section{DAFTAR PUSTAKA}

Abadi, S \& Rusli, Z. (2014). Implementasi Perizinan Usaha Perkebunan. Jurnal Administrasi Pembangunan, 2(3), 227-360.

Adhynugraha, S. (2006). Potensi dan Permasalahan Pengembangan Perkebunan Kelapa Sawit Skala Besar di Kalimantan Timur. Jurnal Borneo Administrator, 2(2), 67-82.
Awaluddin. (2016). Keluhan Kesehatan Masyarakat Akibat Kabut ASAP Kebakaran Hutan dan Lahan di Kota Pekanbaru. Jurnal Endurance, 1(1), 37-46.

Barri, M.F., dkk. (2016). Potret Alih fungsi di Sumatera Utara, Kalimantan Timur dan Maluku Utara. Bogor: Forest Watch Indonesia.

Darjono. (2003). Pengalaman Penegakan Hukum yang Berkaitan dengan Kebakaran di Areal Perkebunan dan HTI Rawa Gambut. Prosiding Semiloka (with English summary), Palembang,73-104.

Darmawan, B., dkk. (2016). Pengelolaan Keberlanjutan Ekosistem Hutan Rawa Gambut Terhadap Kebakaran Hutan dan Lahan di Semenanjung Kampar, Sumatera. Jurnal Manusia dan Lingkungan, 23(2), 195-205.

Garrard, G. (2004). Ecocriticism. New York: Routledge

Hardiningtyas, P.R. (2015). Ekokritik: Ritual dan Kosmis Alam Bali dalam Pusisi Saiban Karya Oka Rusmini. Prosiding Ecology of Lanugage and Literature: Ekologi Bahasa dan Sastra, Banjarmasin: Jurusan Pendidikan Bahasa dan Seni, FKIP, Universitas Lambung Mangkurat, 125-.136.

Masykur. (2013). Pengembangan Industri Kelapa Sawit Sebagai Penghasil Energi Bahan Bakar Alternatif dan Mengurangi Pemanasan Global. Jurnal Reformasi, 3(2), 96-107.

Mills, M.B \& Huberman, A.M. (1984). Qualitative Data Analysis: A Sourcebook of New Methods. Beverly Hills: Sage Publication.

Pranoto, N. (2014). Sastra Hijau Pena yang Menyelamatkan Bumi. Seminar Nasional Bahasa dan Sastra dalam Perspektif Ekologi dan Multikulturalisme, Yogyakarta: Jurusan Bahasa dan Sastra Indonesia, FBS, UNY, 3-19. Simarmata, J.E., Rauf, A., \& Hidayat, B. (2017). Kajian Karakteristik Fisik Tanah di Lahan Perkebunan Kelapa Sawit: Kebun Adolina PTPN IV pada Beberapa Generasi Tanam. Jurnal Ilmu Pertanian Indonesia, 22(3), 191-197.

Tayibnapis, A. Z. (2013). Analisis Kepemilikan Asing dan Strategi Pengendalian Dominasinya dalam Perekonomian Indonesia. Jurnal Ilmiah Sosial dan Humaniora, 6(1), 42-56. 